\title{
IMPLIKASI KONFLIK HISTORIS ISLAM-KRISTEN BARAT TERHADAP MUNCULNYA STIGMATISASI PERMUSUHAN
}

\section{Mufammad Yusuf}

Fakultas Ushuluddin Universitas Islam Negeri Sunan Kalijaga Yogyakarta Jalan Laks. Adi Sucipto Yogyakarta

\begin{abstract}
The current conflict between Islam and Christian (west) originally rooted on the historical conflict which has happened for long time ago. The conflict has been begun from the success of Islam expansion to western countries. The conflict has got worse when the west enable to move Islam domination in which it affected on the stigmazation on the followers. They discredited each other both in theologically and other aspects. All conflicts including Islam-Christian conflict is 'sunnatullah', something unavoidable, which bring both negative-destructive and positiveconstructive effect. In fact, the conflict tends to be negative-destructive. Colonialism which has been continually followed with missionarism and orientalism worsen the situation. This article discusses the implication of historical conflict on stigmatization done by the followers. Moreover, it tries to offer altemative solution, that is, providing a dialogue as a bridge to resolve the conflict. It is expected to stifle the conflict and gradually to shift the conflict into mutual undestanding relationship.
\end{abstract}

Key words: historical conflict, Islam, West Christian, stigmatization

Ulul Albab, Vol. 9 No. 2, 2008 


\section{Pendahuluan}

Telah menjadi rahasia umum, hubungan Islam dan Kristen Barat sampai detik ini mengalami pasang surut. Terkadang hubungan keduanya baik, pada saat yang berbeda memanas kembali, namun acapkali yang domin-an adalah hubungan yang negatif, saling mencurigai, saling tuduh dan penuh nuansa konfliktual. Apabila ditelisik secara historis, sebenarnya hubungan keduanya telah terjadi berabad-abad yangsilam, meskipun bersifat fluktuatif. Persinggungan Islam-Barat telah ada sejak awal Islam (klasik) ketika lslam sebagai agama yang dibawa Muhammad SAW hadir di muka bumi ini. Selama rentang waktu sepanjang itu, hubungan keduanya lebih banyak dilalui dengan konflik-konfrontasi ketimbang kerjasama dan saling memahami. Konflik historis antara dua agama Ibrahim (Abrahamic Religions) diawali dengan keberhasilan ekspansi Islam ke dunia Barat (Eropa) awal abad ke-8 dan diperparah terjadinya Perang Salib, kolonialisme Barat, misionarisme, dan aktivitas orientalisme.

Konflik historis tersebut tampaknya terus berlanjut hingga kini. Salah satu bukti yang paling spektakuler adalah tragedi pengeboman terhadap World Trade Centre (WTC) dan markas Pentagon di Washington DC di New York yang luluh-lantak dan menewaskan ribuan orang pada 11 Septem-ber 2001 yang silam. Belum lagi peristiwa bom Bali I dan Il yang menewaskan ratusan nyawa manusia, yang mayoritas orang asing. Sejak tragedi 11 September 2001 dan rentetan tragedi kemanusiaan yang memilukan tersebut, hubungan Islam-Kristen Barat kian memanas. Alhasil, klaim Barat terhadap stigma Islam sebagai agama teroris, agama pedang, agama violence (kekerasan) dan sederet label buruk lainnya kian mengemuka di publik Barat, bahkan mungkin masyarakat dunia. Tak dapat dipungkiri, streotyping antar keduanya yang terjadi hingga masa kontemporer ini sejatinya telah berurat akar dan merupakan konsekuensi logis dari konflik historis.

Dalam artikel singkat ini, penulis mencoba mendiskusikan konflik historis yang melibatkan Islam-Kristen Barat serta implikasinya terhadap stigmatisasi permusuhan antar kedua agama Ibrahimik tersebut. Dalam konteks ini, stigmatisasi yang dimaksud adalah pelabelan negatif yang sama- 
sama dilakukan oleh sebagian komunitas umat Islam terhadap Kristen (Barat) dan sebaliknya. Selain mengeksplanasikan sejarah konflik lslam-Kristen Barat dan stigmatisasi yang dilakukan masing-masing komunitas agama Semit ini, penulis akan coba menawaran solusi yakni dialog.

\section{Konflik Historis: dari Ekspansi Islam hingga Orientalisme}

Secara historis, agama Kristen telah berhubungan dengan agama Islam selama lebih dari empat belas abad. Rentang waktu yang demikian panjang dan terus-menerus tersebut telah menjadi saksi dari berbagai perubahan dan naik-turunnya batas-batas kebudayaan (culture) dan peradaban (sivilization) dan teritorial antara keduanya. Ia juga ditandai dengan periode panjang konfrontasi sekaligus kerjasama proaktif yang produktif. Tetapi pola hubungan yang paling dominan antara kedua tradisi keimanan ini adalah permusuhan, kebencian, dan kecurigaan ketimbang persahabatan dan saling memahami (Shihab, 1999: 95).

Kendatipun terdapat banyak kesamaan teologis, di sepanjang sejarah, hubungan Islam dan Kristen Barat acapkali diwarnai konflik. Konflik ini antara lain disebabkan upaya para pejuang Islam dan para misionaris Kristen dalam memperebutkan kekuasaan dan umat. Konfrontasi telah melibatkan berbagai peristiwa, seperti ditaklukkannya Byzantium awal (Roma Timur) oleh Islam pada abad ke-7, Perang Salib pada abad ke-11 dan ke-13, pengusiran bangsa Moor dari Spanyol, ancaman kerajaan Ustmani terhadap Eropa, ekspansi, dan dominasi kolonialisme Barat pada abad ke-15 dan ke16, pendirian negara Israel dengan usaha untuk me-Yahudikan kota suci Yerussalem, hingga penegasan kembali Islam dalam arena politik (Esposito, 1986: 171).

Ekspansi Islam dalam waktu seratus tahun pasca wafatnya Nabi Muhammad SAW, para penggantinya (baca: khulafa') berhasil mendirikan dinasti, kerajaan, kesultanan -apapun nama dan bentuk sistem kenegaraannya- yang sukses menundukkan kerajaan Byzantium (Roma Timur). Selain itu, tentara Muslim juga dengan gemilang menaklukkan kerajaan Persia, 
Syria, Irak, Mesir, dan bergerak memasuki Afrika Timur serta bagian-bagian dari Eropa Selatan hingga memerintah dan menguasai hampir seluruh Spanyol, Mediterania, Sisilia, dan Anatolia. (Esposito, 1994: 48-49).

Di beberapa tempat seperti Palestina, Syria, Mesir, afrika Utara, dan Turki, Islam muncul dengan mengalahkan Kristen. Memori berbagai kekalahan tersebut hingga kini masih ada di benak masyarakat Barat sehingga menimbulkan ketakutan pada Islam terutama ketika tentara Turki Utsmani mengepung kota Wina dari tahun 1529 hingga tahun 1683 (Goddard, 2000: 205).

Penyebaran Islam yang begitu cepat merupakan ancaman bagi Kristen di selurıth dunia, baik secara teologis maupun politis. Ketakutan terhadap Islam (Islamophobia) misalnya, dilontarkan Maxim Radinson yang mengemukakan bahwa kaum Muslim merupakan ancaman terhadap Kristen Barat jauh sebelum mereka sendiri menjadi masalah (Radinson, 1974: 9).

Peristiwa besar lainnya yang merupakan pangkal konflik adalah Perang Salib yang terjadi pada abad XI hingga XIIl. Perang Salib adalah fakta sejarah tak terelakkan yang menggambarkan betapa kentaranya konflik Islam dengan Kristen Barat. Bagi kaum Muslim, file tentang Perang Salib itu tak bisa terlupakan dan bahkan tetap hidup. Perang Salib menandai awal agresi dan imperialisme Kristen Barat, sebuah kenangan permusuhan Kristen terhadap Islam yang akan terus berlanjut. Jika banyak orang Barat menganggap orang Islam sebagai pemeluk agama Pedang, maka kaum Muslim selama berabad-abad telah membicarakan ambisi dan mentalitas tentara Salib Barat yang imperialistik.

Kenangan traumatis tersebut terus membekas dan bersemayam di benak umat Muslim hingga detik ini. Konflik mereka terus berlanjut selama masa Ustmaniyyah, melalui arus kolonialisasi Eropa, dan akhirnya ke dalam per-saingan negara-negara adidaya pada abad ke-20. Perang Salib dan kerajaan Ustmaniyyah menunjukkan dengan jelas meskipun Kristen dan Islam mempunyai akar teologis yang sama, namun persaingan kepentingan politik dan agama antara keduanya lebih banyak menghasilkan sejarah konfrontasi dan peperangan (Esposito, 1992: 50-55). 
Pada masa reformasi Gereja, Islam dijadikan obyek dalam polemik di antara kaum Kristen, yakni sebuah lambang bahaya anti-Kristus. Hal ini dapat disimak dari komentar Martin Luther sebagaimana dikutip Albert Hourani memandang Islam sebagai agama kekerasan, anti rasionalitas, dan agama pedang (Hourani, 1983: 10).

Pada abad-abad berikutnya, Islam terus dipergunakan sebagai entitas yang jelek bagi penulis Kristen Barat. Voltaire dalam buku Fanaticism or Muhammad the Prophet, misalnya, menggambarkan sosok Nabi Muhammad SAW sebagai tiran yang teokratis. Stereotip tradisi agama yang statis, irasional, tidak ada kemajuan dan anti-modern ini diabadikan oleh pakar dan teori pembangunan dalam abad ke-20. Emest Renan memandang bahwa Islam tidak sesuai dengan sains, kaum Muslim tidak mampu belajar dan tidak mau membuka diri terhadap gagasan-gagasan baru yang muncul (Hourani, 1983: 12).

Pada masa kolonialisme Barat tepatnya abad ke-19, terjadi pergeseran kekuasaan. Kolonialisme Barat mendominasi sejarah kaum Muslim. Negaranegara Muslim atau negara-negara mayoritas berpenduduk Muslim hampir semua -kalau tidak mau dikatakan semuanya- jatuh ke pangkuan kolonialisme Barat. Indonesia jatuh ke tangan Belanda dan Malaysia dijajah Inggris adalah sedikit contoh bagaimana praktik kolonialisme Barat demikian mendera dunia Muslim. Runtuhnya kekuasaan Islam telah mengubah posisi dan nasib umat Islam. Kaum Muslim "dipaksa" harus bertahan menghadapi ekspansi Barat yang gencar. Kolonialisasi dan Imperialisme Barat mengancam sejarah dan identitas politik dan religio-kultural Islam (Esposito, 1996: 63).

Kolonialisme Barat, kemudian diikuti dengan aktivitas misionarisme dan orientalisme yang dijalankan Barat kian mengukuhkan dan meyakinkan kebencian umat Islam terhadap mereka (Shihab, 1999: 98).

Kolonialisasi pada faktanya melahirkan kegiatan Kristenisasi dan orientalisme. Eropa tidak hanya datang dengan tentara dan birokratnya, tetapi juga datang dengan membawa misionaris. Kaum Muslim menganggap para pendeta dan lembaga-lembaga misionaris semisal gereja, rumah sakit, 
sekolah, dan penerbitan merupakan senjata imperialisme yang efektif untuk menggantikan lembaga-lembaga pribumi (Esposito, 1996: 64).

Sementara terkait literatur yang ditulis orientalis, selain Voltaire sebagaimana telah disinggung di atas, tidak sedikit orientalis periode awal yang menulis negatif tentang Islam dan figur Nabi Muhammad SAW. Tidak jarang kepercayaan dan praktik politeisme, minum-minuman keras dan promiskuitas seksual dinisbatkan pada Islam dan Nabi Muhammad SAW. Sebagian besar Muslim merasa sakit hati dengan karya-karya tulis yang ditelorkan para orientalis sedikit yang menilai Islam secara positif. Kalangan Muslim memandang tujuan kaum orientalis adalah mencetak karya-karya literatur anti-Islam dan membangun berbagai teori yang didasarkan pada kesalahan persepsi dan distorsi (Shihab, 1999: 99). Senada dengan paparan Amin Abdullah dalam sebuah karya pentingnya Studi Islam: Historisitas atau Normativitas? (Abdullah, 2002: 207).

\section{Stigmatisasi Permusuhan}

Aroma konflik Islam-Kristen Barat hingga kini tidak bisa lepas dari faktor kesejarahan sebagaimana telah diuraikan di muka. Stereotip yang muncul tentang kedua agama itu banyak didengungkan melalui berbagai literatur. Sejarah interaksi Islam - Kristen Barat - selain yang telah disinggung sebelumnya- telah melahirkan karya tulis dari masing-masing pemuka agama yang bertujuan mendiskreditkan dan memojokkan agama lawan dengan menelanjangi kelemahan dan kekurangannnya sembari menonjolkan keunggulan ajaran agama yang dianutnya.

Sederet penulis sebagaimana dipaparkan Alwi Shihab telah menghiasi lembaran sejarah pencitraan negatif kedua agama tersebut (Shihab, 1999:4748). Mereka saling menyerang satu sama lain terutama dalam hal doktrin agama. Selama hampir dua abad mulai abad ke-7 hingga abad ke-9. Dari pihak Kristen diwakili oleh St. John of Damascus (675-753), Theodore Abu Gurrah (740-825), Catholicos Thimothy (728-823), dan Ammar al-Basri (800850). Tulisan mereka berkisar pada dua tema sentral; pembenaran doktrin 
Kristen di satu pihak dan penolakan kenabian Muhammad SAW dan otentisitas al-Qur'an-di lain pihak.; Sementara: dari pihak -Islam diwakili oleh Ali bin Sahl al-Thabäri (w. 855) dengan karya berjudul alRadd 'alâ al Nashâa (sanggahan terhadap Kaum Nasrani), dan karya al-jahiz (776869) dengan judul yang sama menjelaskan posisi al-Qur'an tentang distorsi yang dilakukan oleh umat Kristen terhadap ajaran Isa as.

Pada abad ke-11 dan ke-12, di pihak Kristen tercatat penulis Elias alNasibi (975-1046) dan Paus Gregorius VII (1020-1085) yang berupaya membuktikan kebenaran. agama Kristen dan menunjukkan kontradiksi dalam ayat-ayat al-Qur'an. Di pihak Islam tercatat penulis Ibnu Hazm (9941064), dengan karyanya alFishal fi al-Milal Wa al-Ahwa' Wa alNihal (Penjelasan tentang Aliran-Aliran agama dan Sekte-sekte). Dalam karyanya iru, Ibnu Hazm menelanjangi kelemahan-kelemahan Injil. Imam alHaramain, al-Juwainy (1028-1085) mengkritik perubahan-perubahan pada Perjanjian Lama (Old Testament) dan Perjanjian Baru (New Testament) dalam buku Syifa' al-Ghalil fi Bayân mâ Waqâ'a fi al Taurât wa allnjil min alTabdil (Pelepas Dahaga melalui Penjelasan terhadap Perubahan yang Terjadi atas Teks Taurat dan Injil).

Imam al-Ghazali (1059-1111) melalui karya al-Radd alJamil li-Ilahiyyat Isa bi Sharîh alInjil (Sanggahan Indah tentang Ketuhanan Isa dalam Teks Injil). Kemudian, ada Ibnu Taymiyyah (1263-1328), dengan buku berjudul alJawab alShahih liman Baddala Din alMasîh (Jawabain yang Tepat bagi Mereka yang telah Mengubah Agama al-Masih). Saling serang antara kedua pemeluk agama ini masih berlanjut sampai era kontemporer. .Tidak hanya masalah doktrinal (teologis) saja yang mereka serang, akan tetapi juga me-nyangkut aspek-aspek lain dari kedua agama itu.

Pandangan Kristen Barat terhadap Islam sangat dipengaruhi oleh stereotipe citra lamá yang ditanamkan sepanjang sejarah: Islam kerap dipandang sebagai agama irasional, anti-logika, statis, mistis, magis yang disimbolkan dengan "Karpet Trbang Aladin"dan "Lampu Aaib" serta "Kah Seribu Satu Malam" (Alf Lailah wa Lailah) di era khalifah Harus al-Rasyid. Paling banter kaum Muslim dipandang hanya sebagai pembawa ilinu pengetahuan 
bukan pencipta ilmu pengetahuan. Citra seperti ini menurut Hassan Hanafi berakar jauh ke belakang terhadap dikotomi nyata antara Islam dan Barat. Islam bersifat mistik, dogmatik dan sektarian; Islam melahirkan fanatisme. Islam dipandang tidak toleran dan tidak menghargai orang lain. Lantaran kaum muslim yang mayoritas tersebar di Asia dan Afrika dipandang sebagian publik Barat, sebagai dunia terbelakang/tertinggal, maka agama Islam secara inhern selalu dikaitkan dengan keterbelakangan (Hanafi; 2003: 92-93).

Sebagian publik Barat memandang, infrastruktur di dunia Muslim ditandai dengan kurangnya ketersediaan kebutuhan pokok (Basic Needs), masalah kekeringan, kelaparan, kemiskinan, pengangguran, perumahan kumuh, dan seterusnya. Sementara dari aspek suprastruktur, oleh Barat dicirikan sebagai buta huruf, penindasan, monolitisme, militerisme, totalitarianisme, pelanggaran HAM, isu gender, problem minoritas, korupsi, kekacuan dan sebagainya. Tidak sedikit media massa Barat yang menggambarkan Islam sebagai pengganti komunisme dan ancaman yang datang dari Timur pasca jatuhnya rezim Sosialis pada tahun 1991. Islam juga selalu dikaitkan dengan kekerasan, terorisme, pertumpahan darah, perang sipil, hukum pidana yang kejam, tradisionalisme, politik diktator, pengekangan intelektual, dan citra buruk lainnya. ${ }^{1}$ Bahkan, beberapa orang Kristen pada abad pertengahan menganggap agama Islam sebagai salah satu "Bid'ah Kristen". Dalam pandangan Kristen, Islam dipandang oleh orang Kristen Barat sebagai musuh politik dan agama yang harus dihancurkan dan dibasmi (Cowar, 1999:-46).

Komentar negatif terhadap. Islam acapkali dilancarkan beberapa orientalis dan beberapa pemikir Barat, semisal Gairdner sebagaimana dikutip Mahmoud Ayyoub yang mengatakan bahwa Islam menyebar bukan karena memiliki nilai yang ditawarkan, tetapi karena tidak memberikan tuntutan-tuntutan moral terhadap penganutnya (Shihab, 1999: 214). Penilaian yang negatif juga diutarakan oleh Hendrik Kraemer, seorang misionaris yang menyebut Islam sebagai agama yang sungguh-sungguh dangkal dan tidak memiliki nilai untuk ditawarkan kepada manusia. Lebih lanjut menurutnya, Islam merupakan agama "teka-teki", karena meski tidak

Ulul Albab, Vol. 9 No. 1, 2008 
memiliki kedalaman dan orisinalitas tetapi mampu mengungguli agamaagama lain dalam menciptakan superioritas yang absolut dalam jiwa para penganutnya.

Keangkuhan Barat dalam mencitrakan Islam sebagai agama irasional dan anti-intelektual sebenarnya tidak mendasar dan ahistoris, bahkan dapat dinilai karena faktor kecemburuan. Hal ini sebagaimana diungkapkan Charles Kimball dalam buku berjudul When Religion Becomes Evil

Citra Islam yang populer di Barat adalah agama yang tidak cerdas dan anti-intelektual segera sirna ketika kita melihat secara sekilas sejarah Islam. Kesalahan ini sangat ironis mengingat peradaban Islam telah membantu membentuk masyarakat Barat seperti yang kita lihat. Ketika Eropa merana di Masa Kegelapan, peradaban Islam tumbuh subur dari Spanyol hingga India. Selama beberapa abad, kaum Muslim memimpin dunia dalam berbagai bidang, seperti matematika, kimia, kedokteran, filsafat, navigasi, arsitektur, holtikultura, dan astronomi. Kaum Muslim bangga dengan sejarah dan peradaban mereka (Nur Hadi, 2001: 172-172).

Hampir senada dengan Charles Kimball, Mustafa Ceric, ulama besar Bosnia-Herzegovina, mengemukakan bahwa ada persepsi yang sangat kontradiktif dalam memandang Islam. Timur menganggap Islam sebagai solusi, sebaliknya Barat menganggap sebagai masalah. Perbedaan persepsi ini, kata Mustafa Ceric, selanjutnya menimbulkan stereotip negatif. Banyak orang Barat, termasuk para intelektualnya, memandang Islam seperti mereka memandang komunisme di era Perang Dingin (Cold War).

John Obert Voll mencatat, di dunia Islam dengan mendasarkan pada pengalaman-pengalamannya pada abad ke-18 pada tahun 1970-an yang merupakan perkembangan yang dramatis, juga pada permulaan abad ke15 yang mengalami transformasi utama demi kelangsungan dan perubahan. Sehingga menjadi jelas, bahwa Islam bukan merupakan kekuatan yang mati, dan telah terbukti kemampuannya dalam berbagai cara dari revolusi sampai dengan reorientasi ideologi-ideologi yang dominant (Voll, 1997: 431-32). 
Stigma Islam sebagai agama kekerasan, teror, anti-HAM, anti-demokrasi, pemasungan perempuan, dan seterusnya kiat menguat tatkala mendapat momentum pasca peristiwa 11 September 2001. Hal lain yang memperkuat stigma tersebut adalah realitas dunia Islam yang kebanyakan dipimpin oleh kekuasaan otoriter. Cara pandang Barat atas Islam yang peyoratif merupakan generalisasi yang salah kaprah dan bersifat generalisir "pukul rata" sekaligus merupakan kegagalan dalam memahami peradaban Islam secara holistik-komprehensif. Sebagian masyarakat Barat masih terkungkung pada persepsi negatif itu, sehingga hanya mampu melihat dengan sebelah mata atau persepsi "kacamata kuda". Meskipun di sisi lain, pada akhir-akhir ini komunikasi Barat dan Islam berjalan secara lebih intensif dan intim melalui kajian yang lebih objektif dan ilmiah yang menghasilkan produk akademik. Sayangnya, pemahaman representatif yang mewakili Islam ini belum menyeruak dan mengemuka dalam ruang publik Barat secara umum. Kalaupun ada masih bersifat parsial, sporadis dan hanya menempati ruang yang sempit dan sangat terbatas.

Fakta, banyaknya ketidakadilan yang menimpa umat Muslim di negaranegara Barat tidak lain bermula dari akar masalah persepsi yang timpang tersebut. Diskriminasi sosial yang kerapkali menimpa sebagian umat Muslim di dunia Barat diakibatkan oleh pemahaman yang sempit dan bias dalam memandang Islam yang kerap diidentikkan sebagai agama yang mengajarkan kekerasan, ketidakadilan, eksklusif dan prilaku negatif lainnya. Dalam persepsi sebagian publik Barat, Islam dikaitkan erat dengan model agama yang mendidik terorisme dan kekerasan.

Seperti banyak disinggung di awal, citra agama Kristen tidak bisa dilepaskan dari citra Barat. Sama seperti citra Islam di mata Barat, citra Kristen Barat juga ditanamkan dalam media massa dan literatur Muslim yang diambil dari sejarah, pergerakan sosial, filsafat, ideologi dan aspek-aspek lain. Citra tersebut bertujuan membuat karakteristik "lawan", yang dikokohkan untuk menciptakan polarisasi dan legitimasi diri. Legitimasi ini, keinginan Barat untuk meligitimasi bahwa Islam adalah agama ekstrem yang berbaju ideologis. 
Abad pertengahan, Barat dicitrakan melahirkan Perang Salib yang dianggap oleh sebagian umat Islam sebagai bentuk kolonialisme Barat pertama. Barat menginvasi dunia Muslim dengan menggunakan legitimasi agama (Kristen). Setelah kolonialisme jilid I, kemudian berlanjut pada kolonialisme modern yang kurang lebih mempunyai tujuan yang sama. Setelah dekolonialisasi, globalisasi, internasionalisasi menjadi bentuk baru hegemoni atas nama pasar dan revolusi informasi. Barat mpil dengan arogansi epistemologis yang begitu saja melupakan Islam dalam membentuk basis dan akar ilmu pengetahuannya. "Superioritas Kompleks" menghinggapi masyaràkat Barat dan melabeli dunia non-Barat dengan "Inferioritas Kompleks". Barat telah mereduksi sejarah dunia menjadi sejarah Eropa. Sekularisme dan Materialisme yang dijadikan "Kitab Suci" Barat telah memarjinalkan (meminggirkan) dan - kalau perlu menafikan- peran agama. Tuhan telah kehilang an perannya lagi, dengan perkataan lain meminjam terminologi Nietzsche "Tuhan telah Mati".

Hassan al-Banna, Maulana al-Maududi, dan Sayyid Qutb -para ideolog Islam radikal yang pemikiran dan aktivitasnya banyak mempengaruhi gerakan fundamentalis Islam- memandang Barat sebagai musuh historis Islam sebagamaina diperlihatkan melalui Perang Salib, kolonialisme, dan Perang Dingin. Menurut mereka, Barat mengancam Islam secara politis, ekonomis, dan religio-kultural (Hanafi, 2003: 94-95).

Munculnya stigma tentang citra Islam di mata publik Barat dan citra Barat di mata Islam selain digambarkan lewat literatur (baca: buku) -sama seperti yang terjadi dunia Muslim- juga digambarkan melalui pemberitaan media pers. Di ruang publik, media massa merupakan subyek yang mengkonstruksi realitas, lengkap dengan pandangan bias dan pemihakan-nya. Kelompok berideologi dominan dan penguasa modal yang akan meng-uasai media. Konsekuensinya adalah lahirnya berbagai distorsi, misrepresen-tasi, miskomunikasi, dan misinterpretasi dalam pemberitaan yang tidak dapat dihindari lagi, termasuk pemberitaan yang dinilai merusak citra Islam di media massa milik Barat. Kesimpulannya, bagi sebagian orang Barat, Islam merupakan agama pedang, agama jihad, agama kekerasan dan agama ter- 
belakang. Sebaliknya, bagi kaum Muslim, Kristen adalah agama Perang Salib sekaligus agama misionaris yang berambisi tinggi untuk menghegemoni dunia.

\section{Memahami Konflik: Merajut Dialog}

Konflik merupakan bagian tak terpisahkan dan tidak dapat dihindarkan dari kehidupan dan relasi-interaksi manusia dari berbagai entitas dan kompleksitasnya. Pepatah Arab mengatakan bahwa konflik adalah min lawazim alhayah (keniscayaan hidup). Konflik merupakan konsekuensi logis dari kehidupan sosialitas umat manusia. Sebagai makluk sosial (zoön politikon), sepertinya sudah menjadi naluri manusia untuk melakukan inter-aksi sosial dalam berbagai dimensi. Dalam diskursus teori sosial, interaksi sosial menimbulkan dua bentuk interaksi, yaitu proses yang asosiatif (processes of association) dan proses yang disosiatif (processes of dissociation). Meskipun konflik merupakan suatu proses disosiatif yang tajam, akan tetapi konflik sebagai salah satu bentuk proses sosial juga mempunyai fungsi positif. Konflik yang dapat dikendalikan dan lunak dapat menjadi kontrol bagi kelangsungan interaksi sosial. Sepanjang konflik tidak berlawanan dengan pola-pola hubungan sosial dalam struktur sosial tertentu, maka konflik itu bisa bersifat positif.

Suatu konflik dapat membawa akibat positif ataupun negatif tergantung pada persoalan yang dikonflikkan dan struktur sosial yang menyangkut suatu tujuan, nilai dan kepentingan dari konflik itu. Oleh karena itu, konflik memungkinkan adanya penyesuaian kembali normanorma dan hubungan sosial dalam kelompok bersangkutan sesuai dengan kebutuhan individual maupun sosial. Namun apabila benih-benih konflik dibiarkan berkembang, maka kemungkinan besar keutuhan kelompok akan terancam (Soekanto, 1995: 109).

Selain itu, konflik juga dapat membantu memperkuat kembali normanorma sosial yang hampir tidak berfungsi dalam kehidupan masyarakat. Dalam konteks ini., konflik merupakan proses penyesuaian (adaptability) 
antara norma-norma sosial yang lama dengan norma-norma sosial yang baru sesuai dengan kepentingan yang dibutuhkan masyarakat pada saat tertentu. Jika konflik dapat diselesaikan, maka keseimbangan dapat ditemukan kembali (Abdulsyani, 2002:158).

George Simmel sebagaimana dikutip Doyle Paul Johnson mengatakan bahwa konflik juga dapat menghasilkan pembentukan kelompok baru yang terdiri dari orang-orang yang sebelumnya acuh tak acuh atau malah bertentangan menjadi kelompok persekutuan (Johnson, 1986: 273). Konflik juga dapat menjadi aktor perubahan. Dalam konteks tersebut, John Paul Lederach mengatakan: "conflict is a nomal in human relationship, and conflict is a motor of change" (Lederach, 2003: 4-5).

Bertitik tolak dari beberapa asumsi di atas, pada level tertentu, konflik Islam-Kristen Barat tidak selamanya membawa implikasi negatif. Konflik dapat dijadikan indikator bahwa sikap akomodasi dan pola interaksi sebelumya ada yang "tidak beres", dan mungkin "hang", karenanya dibutuhkan pembaruan (Tajdid) dan perubahan (Tagyir) terhadap hubungan itu. Dengan adanya konflik, umat lslam dan Kristen Barat seharusnya dapat mengevaluasi diri (Self Correct) - atau dalam bahasa popular Islam Muhasabah -ams sikap dan tindakannya selama ini, sehingga pola interaksi antara keduanya dapat diperbaiki atau direkonstruksi dalam rangka menuju kesaling pengertian dan kerjasama.

Memang, untuk merajut kembali sesuatu yang telah kusut bahkan hampir purus, bukan merupakan hal mudah untuk dilakukan. Itulah sebabnya, perlunya kesadaran baru dengan cara menata persepsi, mengubah cara pikir dan membuka hati oleh masing-masing kubu - Barat Kristen dan Timur Islam- dengan duduk bersama tanpa dihinggapi unsur-unsur negatif ke-curigaan, kedengkian, keirian dan sikap permusuhan. Dengan demikian dapat diharapkan bahwa kesatuan agama Semitik-Ibrahimik tidak hanya berhenti di arasy normatif yang hanya bisa dipahami hanya oleh kalangan terdidik dan pemikir, tapi harus digelindingkan sampai ke relung-relung jantung kehidupan di kalangan umat masing-masing secara praksis dalam ranah sosiologisempirik.

Ulul Albab, Vol. 9 No. 2, 2008 
Meskipun fakta di lapangan masih berbicara lain, konflik antara umat Islam-Kristen Barat selama ini justru lebih banyak -kalau tidak mau di-katakan seluruhnya- membawa keretakan dan disintegrasi sosial antar keduanya. Alih-alih membawa perbaikan, konflik Islam-Kristen Barat justru menampilkan wajah garangnya dan bersifat laten. Konflik keduanya lebih banyak bernilai destruktif daripada konstruktif. Memang bukan masalah yang mudah untuk mengelola konflik menjadi potensi yang positif-konstruktif, terlebih keduanya telah sekian lama berkonflik. Oleh karena itu, dibutuhkan semacam "toleransi" untuk mengatasi konflik. Untuk meng-atasi konflik "negatif", Emile Durkheim menawarkan perlunya dibuat kesepakatan (agreement) di antara dua kelompok yang berkonflik. Kese-pakatan ini berisi tentang komitmen bersama tentang berbagai peraturan atau nilai dasar bersama yang dapat mengendalikan konflik (Johnson, 1986: 190).

Untuk menggapai kesepakatan diperlukan dialog intens dan kontinuitas. Dialog antar umat beragama adalah pertemuan di antara orangorang atau kelompok-kelompok yang memiliki agama yang berbeda yang bertujuan mencapai pengertian bersama mengenai masalah-masalah tertentu dengan memberikan penghargaan dan apresiasi serta saling bekerjasama untuk menemukan rahasia arti kehidupan (secret of the meaning of life) (Ali Mukti, 1981: 37). Dialog merupakan salah satu cara interaksi sosial untuk membangun the common vision mengatasi perselisihan dan mewujudkan harmoni. Nurcholish Madjid mendedahkan bahwa dialog merupakan wujud mencapai keserasian. Hal ini lantaran dialog melibatkan adanya pandangan dan pendekatan positif suatu pihak kepada pihak-pihak lain. Bagi Nurcholish Madjid, dalam artikelnya "Dialog Agama-agama dalam Perspektif Univer-salisme al-Islam", dengan adanya dialog pada gilirannya akan menghasilkan pengukuhan dan saling pengertian (Esposito, 1994: 6-7).

Dialog yang dibangun tidak boleh hanya sebatas retorika dan seremonial belaka, atau meminjam istilah Paul F. Knitter "toleransi yang malas, lazy tolerance", yang hanya bermanis-manis muka, tetapi lebih dari itu, 
hendaknya bisa menýentuh substansi permasalahan dan dapat dipraksiskan dalam bentuk yang konkret. Dialog yang dikembangkan juga tidak boleh lagi bertujuan untuk menelanjangi kelemahan agama lain dan menobatkan orang lain dari keyakinannya, melainkan lebih pada berbagi pengalaman dari tradisi keagamaan masing-masing pemeluk agama (Asroni, 2007: 42-43). Dialog tidak mesti dilakukan secara formal, namun juga dapat dilakukan dalam momen dan situasi apapun menyangkut problem kehidupan sehari-hari. Dialog juga tidak harus membahas tentang hal-hal yang bersifat teologis, tetapi dapat pula mendiskusikan hal-hal yang bersifat praktis dan aktual, semisal masalah kemiskinan, pendidikan, hak-hak minoritas agama, masalah lingkungan, bias gender dan lain-lain. Dialog semacam ini dengan meminjam terminologi Azyumardi Azra sebagai "Dialog Kehidupan" (Dialogue of Life) (Azra, 2002: 216-217). Dengan demikịan, dịalog sẹtidaknya dapat meng-urangi ekses konflik historis Islam-Krisțen Baraț yang lạma berkecamuk selama berabad-abad lamanya, baik secara psikologis maupun fisis.

\section{Simpulan}

Konflik historis yang melibatkan Islam-Kristen Barat telah berlangsung berabad-abad lamanya, tepatnya, diawali dengan ekspansi Islam ke dunia Barat. Konflik historis tersebut kian meruncing dengan adanya kolonialisme Barat yang kemudian diperparah dengan lahirnya "anak kandung" kolonialisme yakni misionarisme dan orientalisme.

Konflik historis antara dua tradisi agama Ibrahimi (Abrahamic Religions) tersebut berimplikasi terhadap stigmatisasi permusuhan yang dilakukan oleh sebagian kedua umat beragama. Mereka saling mendiskreditkan satu sama lain, baik aspek teologis maupun aspek-aspek lainnya. Konflik' -termasuk konflik historis Islam-Kristen Barat-merupakan "sunnatullah", sesuatu yang tidak dapat dihindari. Konflik tidak selamanya negatif-destruktif, tetapi dapat juga bersifat positif-konstruktif. Namun faktanya, konflik historis Islam-Kristen Barat lebih banyak bersifat negatif-destruktif dengan berbagai varian "penampakan" dalam kehidupan sosiologis.

Ulul Albab, Vol. 9 No. 2, 2008 
Indikatornya adalah stigmatisasi permusuhan yang terus mengendap di benak sebagian kedua umat beragama tersebut. Untuk mengurai konflik historis tersebut diperlukan dialog serius dengan sebuah kesadaran baru menata ulang persepsi, mengubah cara pikir dan membuka hati oleh masing-masing kubu -Barat Kristen dan Timur Islam- tanpa dihinggapi unsur-unsur negatif kecurigaan, kedengkian, keirian dan sikap permusuhan. Sehingga kesatuan agama Semitik-Ibrahimik tidak hanya berhenti di arasy normatif yang hanya bisa dipahami hanya oleh kalangan yang sangat terbatas, tapi harus menyentuh ke jantung kehidupan sosiologis masing-masing dalam ranah empirik-historis.

Dengan dialog semacam ini, konflik historis Islam-Kristen Barat yang kerap berujung pada stigmatisasi permusuhan, prejudice, dan konfrontasi diharapkan segera berganti menjadi mutual understanding dan kerjasama yang konstruktif.

\section{Daftar Pustaka}

Abdullah, Amin. 2002. Studi Agama: Nomativitas atau Historisitas?. Yogyakarta: Pustaka Pelajar.

Abdulsyani. 2002. Sosiologi: Skematika, Teori, dan Terapan. Jakarta: PT Bumi Aksara.

Asroni, Ahmad., dkk. 2007. Kajian Islam Kontemporer, Jakarta: Lembaga Penelitian UIN Syarif Hidayatullah.

Azra, Azyumardi. 2002. Reposisi Hubungan Agama dan Negara: Merajut Kenukunan Antanumat. Jakarta: Kompas.

Coward, Harold.1999. Pluralisme Tantangan bagi Agama-Agam. Yogyakarta: Kanisius.

Esposito, John L. 1994. Ancaman Islam: Mitos atau Realitas?. terj. Alwiyah Abdurrahman dan MISSI. Bandung: Mizan.

Esposito, John L. 2003. Unholy War: Terror in the Name of Islam. Terjemahan oleh Syafruddin Hasani. Yogyakarta: Ikon Teralitera.

Esposito, John L. (Ed.). 1986. Identitas Islam pada Perubahan Sosial Politik. terj. A. Rahıman Zainuddin. Jakarta: Bulan Bintang. 
Goddard, Hugh. 2000. Menepis Standar Ganda Membangun Saling Pengertian Muslim-Kriste. Terjemahan oleh Ali Noer Zaman. Yogyakarta: Qalam.

Hanafi, Hassan. 2003. Cakrawala Banu Peradaban Global: Revolusi Islam untuk Globalisme, Pluralisme, dan Egalitarianisme Antar Peradaba. Terjemahan oleh Muhammad Saiful Anam. Yogyakarta: IRCiSoD.

Hourani, Albert. 1983. Arabic Thought in the Liberal Age, 1798.193., Cambridge: Cambridge University Press.

Johnson, Doyle Paul. 1986. Sociological Theory Classical Founders and Contemporary Perspectives. Terjemahan oleh Robert M. Z. Lawang. Jakarta: Gramedia.

Lederach, John Paul. 2003. The Little Book of Conflict Transformation. Intercourse, PA: Good Books.

Radinson, Maxim. 1974. The Westem Image and Westem Studies. Oxford: Oxford University Press.

Shihab, Alwi. 1999. Islam Inklusif: Menuju Sikap Terbuka Dalam Beragama. Bandung: Mizan.

Soekanto, Soerjono. 1995. Sosiologi Suatu Pengantar. Jakarta: PT Raja Grafindo Persada.

Umam, Zacky Khairul. 2007. Rekonstruksi Dialog Islam-Barat. (Online), http/ /uruw.republika. co.id, diakses Juni 2007.

Voll, John Obert. 1997. Politik Islam Kelangsungan dan Perubahadan di Dunia Modem. Terjemahan oleh Ajat Sudrajat. Jakarta: Titian Ilahi Press. 